\title{
IMPLEMENTASI MODEL PEMBELAJARAN PROJECT BASED LEARNING (PjBL) DALAM MENINGKATKAN HASIL BELAJAR PESERTA DIDIK PADA MATA PELAJARAN PENDIDIKAN AGAMA ISLAM SMP NEGERI 7 KOTA TANGERANG
}

\author{
Eka Wahyuni*, Fitriana** \\ *Eka946669@gmail.com, **fitriana@umt.ac.id
}

* Alumni Magister PAI Program Pascasarjana, Universitas Muhammadiyah Tangerang

** Dosen Magister PAI Program Pascasarjana, Universitas Muhammadiyah Tangerang

\begin{abstract}
This research is aims to improve learning outcomes in Islamic Relegious Education subject by using Project Based Learning (PjBL) model. This type of research is qualitative with a descriptive-analytic approach. The results of this study indicate that; (1) Implementation of Project Based Learning (PjBL): The first stage is designing learning which includes studying the syllabus, identifying learning materials, determining learning objectives, determining learning strategies and learning methods, determining learning media and resources, and preparing learning instruments. The second stage is the implementation of learning based on plans that have been made previously. The learning runs smoothly with the Project Based Learning (PjBL) steps, which are fundamental questions, compiling a project plan, compiling a schedule, monitoring, testing results, and ending the evaluation of experiences. (2) The results of the application of Project Based Learning (PjBL) are to improve student learning outcomes in the subject of Islamic Religious Education, increase student enthusiasm in learning, increase student interest in learning, train students to think critically, be active, responsible, dare to express opinions, and students can respect the opinions of others. Students are trained to be confident and polite towards older people or adults, besides that students are trained to contextualize the knowledge they have. (3) the obstacle faced is the lack of student activity, because students still seem shy and lack self-confidence.
\end{abstract}

Keywords: Project Based Learning (PjBL), Learning Outcomes and Islamic Religious Education

\section{A. PENDAHULUAN}

$\begin{array}{cccc} & \text { Pembelajaran } & \text { Pendidikan } & \text { Islam } \\ \text { adalah } & \text { sebuah } & \text { proses } & \text { untuk }\end{array}$ mempersiapkan manusia supaya hidup dengan sempurna dan berbahagia, mencintai tanah air, sehat jasmaninya, sempurna budi pekertinya (akhlaknya), teratur fikirannya, mahir dalam pekerjaannya, manis tutur katanya baik lisan maupun tulisan.

Dalam kurikulum Pendidikan Agama Islam dirancang berdasarkan nash Al-Qur'an dan Al-Hadits, yang bertujuan agar manusia mendapat kesejahteraan didunia dan tetap dekat dengan Allah swt.
Kurikulum Pendidikan Islam dirancang agar kehidupan dunia dan ukhrarawi menjadi milik umat-Nya dengan modal iman, amal dan takwa kepada-Nya. Disinilah perbedaan prinsipil kurikulum Pendidikan Islam dengan kurikulum lain yang mempunyai kecenderungan mengutamakan aspek material dengan hasil sehingga proses belajar mengajar tidak berjalan dengan baik dan tujuan pembelajaran belum tercapai.

Dalam proses belajar mengajar terjadi interaksi antara berbagai komponen yaitu guru, peserta didik, tujuan, bahan, alat, metode dan lain-lain. Masing-masing 
komponen saling mempengaruhi dalam memcapai tujuan pembelajaran.Peserta didik adalah komponen yang paling utama dalam kegiatan belajar-mengajar, karena yang harus mencapai tujuan penting dalam pembelajaran adalah peserta didik yang belajar.Maka pemahaman terhadap peserta didik adalah penting bagi guru agar dapat menciptakan situasi yang tepat serta memberi pengaruh yang optimal bagi peserta didik untuk dapat belajar dan mendapatkan hasil yang maksimal.

Menurut Mulyasa (2004:100)

pembelajaran pada hakekatnya adalah interaksi antara peserta didik dengan lingkungannya sehingga terjadi perubahan perilaku ke arah yang lebih baik. Dalam pembelajaran tersebut banyak sekali faktor yang mempengaruhinya, baik faktor internal yang datang dari diri individu, maupun faktor ekternal yang datang dari lingkungan individu.

Hasil belajar pada dasarnya adalah suatu kemampuan yang berupa keterampilan dan perilaku yang baru sebagai akibat dari latihan atau pengalaman yang diperoleh.Hasil belajar pada diri seseorang sering tidak langsung tampak tanpa seseorang melakukan tindakan untuk memperlihatkan kemampuan yang diperolehnya melalui belajar.Pendidikan Agama Islam merupakan pelajaran yang ada di semua lembaga sekolah baik lembaga yang negeri maupun swasta yang memberikan pengetahuan kognitif dan afektif. Untuk Pendidikan Agama Islam di Sekolah Menengah Pertama (SMP) sangat sedikit sekali waktunya, tidak seperti pelajaranpelajaran umum seperti Matematika, Bahasa Indonesia, Bahasa Inggris, dan lain-lain. Walaupun wakyunya sedikit guru Pendidikan agama Islam tidak hanya dituntut untuk menyampaikan materi, tetapi memiliki tanggung jawab besar dalam mencapai tujuan pembelajaran. Selain memiliki banyak kelebihan dalam belajar Pendidikan Agama Islam, tetap saja ada kendala pembelajaran Pendidikan Agama Islam yang dihadapi, seperti penguasaan kelas, menerapkan model pembelajaran yang tepat, dengan adanya hal tersebut penulis melakukan pengamatan di SMP Negeri 7 Kota tangerang.

Selain itu, terdapat permasalahan keagamaan semakin komplek seiring perkembangan zaman.Oleh karena itu, guru Pendidikan Agama Islam harus siap dengan perubahan, seorang guru harus tepat dan efektif dalam meramu materi pelajaran Pendidikan Agama Islam.Untuk menciptakan peserta didik-peserta didik yang berkualitas dan mampu menghadapi perkembangan zaman maka kebutuhan pembaharuan dalam metode merupakan suatu keniscayaan.

Kualitas pembelajaran dapat dilihat dari proses dan dari segi hasil. Dari segi proses pembelajaran dikatakan berhasil dan berkualitas apabila seluruh atau setidak-tidaknya sebagian besar (75\%) peserta didik secara aktif, baik fisik, mental maupun sosial dalam poses pembelajaran, disamping menunjukkan kegairahan belajaran yang tinggi, semangat belajar yang besar dan rasa percaya pada diri sendiri.Sedang dari segi hasil, proses pembelajaran dikatakan berhasil apabila terjadi perubahan yang positif dari peserta didik seluruhnya atau setidak-tidaknya sebagian besar (75\%). Suatu proses belajar mengajar yang efektif dan bermakna akan berlangsung apabila dapat memberikan keberhasilan bagi peserta didik maupun guru itu sendiri.

Dalam pembelajaran Pendidikan Agama Islam di sekolah selama ini para guru lebih menggunakan metode verbalistik, yaitu ceramah dan tanya jawab. Hal ini tidak berarti bahwa metode ceramah tidak baik, melainkan pada suatu saat peserta didikakan menjadi bosan bila guru berbicara terus sedangkan para peserta didik duduk diam mendengarkan. Selain itu kadang ada pokok bahasan yangmemang kurang tepat untuk disampaikan melalui metode ceramah dan lebih efektif melalui metode lain.

Kondisi pembelajaran Pendidikan Agama Islam adalah faktor-faktor yang mempengaruhi penggunaan metode dalam meningkatkan hasil pembelajaran Pendidikan Agama Islam. Jadi metode 
dalam pembelajaran Pendidikan Agama Islam disesuaikan dengan kondisi dan tujuan yang hendak dicapai oleh pembelajaran itu sendiri.

Jika dilihat dari materi yang ada, pelajaran Pendidikan Agama Islam bersifat komplek, sehingga metode yang diterapkanbisa beragam sesuai kebutuhan dan tujuan yang ingin dicapai.Salah satunya bila ditinjau dari aspek tujuannya yang mengarah pada ranah kognitif, afektif, psikomotorik, metode yang bisa digunakan untuk memperdalam kejelasan arti dari materidan peserta didik berperan atau terlibat langsung adalah dengan menggunakan metode.

Model pembelajaran berbasis proyek (project based learning) merupakan suatu motode pengajaran yang mendorong peserta didik untuk mendapatkan pengetahuan baru dengan berdasarkan pengalaman dengan beraktifitas secara nyata.Strategi pembelajaran bersifat praktik industri pada dasarnya membahas tentang strategi pembelajaran bersifat dasar.Artinya, strategi tersebut membahas tentang bagaimana mengajarkan keterampilan dasar kejuruan.Jadi, strategi tersebut belum membahas tentang bagaimana mengajarkan keterampilanketerampilan yang bersifat kompleks.

Dengan menggunakan model pembelajaran project based learning (PjBL)peserta didikakan menggali konten (materi) dengan menggunakan berbagai cara yang bermakna bagi dirinya, dan melakukan eksperimen secara kolaboratif. Model pembelajaran project based learning merupakan investigasi mendalam tentang sebuah topik dunia nyata, hal ini akan berharga bagi atensi dan usaha peserta didik.

Pembelajaran berbasis proyek didukung oleh teknologi terbaru adalah strategi yang pasti untuk mengubah kelas tradisional secara keseluruhan.Kemudian peserta didik belajar dengan terlibat dalam proyek dunia nyata.Hampir setiap aspek perubahan pengalaman mereka.Peran guru bergeser.Dia bukan lagi ahli konten, membagikan informasi dengan potongan berukuran gigitan.
Perilaku peserta didik juga berubah.Alih-alih mengikuti petunjuk guru, peserta didik mengajukan pertanyaan mereka sendiri untuk menciptakan makna mereka sendiri. Bahkan batas kelas pun berubah. Guru masih merancang proyek sebagai kerangka belajar. Namun peserta didik mungkin akan menggunakan teknologi untuk mengakses dan menganalisis informasi dari seluruh pelosok dunia.

Model pembelajaran project based learning (PjBL) dapat digunakan dalam segala aspek bidang studi, model ini juga cocok digunakan pada bidang studi Pendidikan Agama Islam. Karena didalam bidang studi Pendidikan Agama Islam kerap sekali ditemukannya suatu permasalan baru sesuai dengan perkembangan zaman. Dan dengan menggunakan metode pembelajaran project based learning (PjBL) yang bercirikan adanya peraktek nyata sehingga peserta didik dapat berfikir ktritis dan keterampilan memecahkan masalah serta memperoleh sebuah pengetahuan.

Realitas pendidikan Islam saat ini bisa dibilang telah mengalami masa intellectual deadlock.Diantara indikasinya adalah; Pertama, minimnya upaya pembaharuan, dan kalaupun ada kalah cepat dengan perubahan sosial, politik dan kemajuan iptek.Kedua, praktek pendidikan Islam sejauh ini masih memelihara warisan yang lama dan tidak banyak melakukan pemikiran kreatif, inovatif dan kritis terhadap isu-isu aktual.Ketiga, model pembelajaran pendidikan Islam terlalu menekankan pada pendekatan intelektualisme verbalistik dan menegaskan pentingnya interaksi edukatif dan komunikasi humanistik antara gurumurid.Keempat, orientasi pendidikan Islammenitikberatkan pada pembentukan hamba Allah dan tidak seimbang dengan pencapaian karakter manusia muslim sebagai khalifah fi al-ardl. Padahal, di sisi lain pendidikan Islam mengemban tugas penting, yakni bagaimana mengembangkan kualitas Sumber Daya Manusia (SDM) agar umat Islam dapat berperan aktif dan tetap survive di era globalisasi. 
Peneliti memilih SMP Negeri 7

Kota Tangerang sebagai objek dalam penelitian ini, karena menurut pengamatan peneliti bahwa di SMP Negeri 7 Kota Tangerangyang menggunakan sistem yang berorientasi pada keaktifan peserta didik dalam proses pembelajaran. Disamping itu, letak lokasi SMP Negeri 7Kota Tangerang sangat strategis sehingga memungkinkan peneliti bisa lebih intensif dalam melakukan penelitian.Hal inilah yang menjadi pertimbangan dalam memilih lokasi atau objek penelitian.

Berdasarkan atas latar belakang inilah, peneliti tertarik untuk mengadakan penelitian tentang "Implementasi Model Pembelajaran Project Based Learning(PjBL) dalam Meningkatkan Hasil Belajar Peserta Didik pada Mata Pelajaran Pendidikan Agama Islam (Studi Kasus di SMP Negeri 7 Kota Tangerang)".

\section{B. METODE PENELITIAN}

Menurut Omar Muhammad AlToumy, hasil belajar adalah perubahan tingkah laku yang relative menetap dalam diri seseorang sebagai sebab akibat dari interaksi seseorang dengan lingkungannya. Hasil belajar memiliki beberapa ranah atau kriteria dan secara umum menunjuk kepada aspek pengetahuan, sikap, dan keterampilan.

Hasil belajar berkaitan dengan pencapaian dalam memperoleh kemampuan sesuai dengan tujuan yang direncanakan. Dengan demikian tugas guru dalam hal ini adalah merancang instrument yang dapat mengumpulkan data tentang keberhasilan peserta didik mencapai tujuan pembelajaran.

Diantara indikator keberhasilan
dalam proses pembelajaran adalah
perubahan sikap dan tingkah laku peserta
didik, yang terjadi akibat dari penerimaan
dan pemahaman terhadap bahan
pendidikan yang disajikan oleh seorang
pendidik. Penyajian bahan pendidikan
yang diajarkan, sehingga peserta didik
akan lebih mudah menerima dan
memahami serta terkesan untuk
mengamalkannya.

Hal yang menjadi tujuan belajar salah satunya adalah perubahan tingkah laku dalam diri ini. Perubahan yang diharapkan tentunya perubahan yang positif yang mampu membawa individu menuju kondisi yang lebih baik. Dalam proses pencapaian tujuannya, belajar dipengaruhi oleh berbagai hal. Hal inilah yang nantinya mampu menentukan berhasil tidaknya suatu proses belajar. Hasil belajar yang dicapai peserta didik merupakan hasil interaksi antara dua faktor yang mempengaruhi, yaitu faktor internal dan faktor eksternal. Ula (2013:17).

Sebagai suatu proses, keberhasilan belajar ditentukan oleh berbagai faktor. Menurut Ryan (dalam Smith, 1970), ada tiga faktor yang mempengaruhi proses belajar, yaitu: (1)Kativitas individu pada saat beriteraksi dengan lingkungan; (2)Faktor fisiologis individu; (3)Faktor lingkungan yang terdiri dari semua perubahan yang terjadi di sekitar individu tersebut.

Masrun dan Martaniah (1978) berpendapat bahwa faktor-faktor yang mempengaruhi belajar diantaranya adalah: (1)Kemampaun bawaan anak; (2)Kondisi fisik dan psikis anak; (3)Kemauan belajar anak; (4)Sikap murid terhadap guru dan mata pelajaran serta pengertian mereka mengenai kemajuan mereka sendiri; dan (5) Bimbingan.

Secara garis besar, Suryabrata (1989) menyatakan bahwa faktor-faktor yang mempengaruhi hasil belajar dapat digolongkan menjadi dua, yaitu:

a. Faktor-faktor yang berasal dalam diri pembelajar, yang meliputi:(1) Faktor fisiologis; dan (2)Faktor psikologis.

b. Faktor-faktor yang berasal dari luar diri pembelajar, yang meliputi: (1)Faktor sosial, dan (2)Faktor non sosial.

\section{Pengertian Project Based Learning} Lindawati. (Jurnal Radiasi) Project Based Learning adalah suatu pendekatan pembelajaran yang membenturkan peserta didik kepada masalah praktis melalui stimulus 
dalam belajar. Pembelajaran berbasis proyek ini peserta didik dilatih untuk:

a. Bertanggung jawab atas apa yang menjadi tanggung jawabnya.

b. Menilai rencana kerja dan bekerja sesuai rencana yang telah dibuat.

c. Berkompetensi secara sehat.

d. Menerapkan atau mencari ilmu yang telah dipelajari.

Untuk memahami pembelajaran jenis ini, berikut ini dipaparkan terlebih dahulu definisi oleh para ahli :

a. Robert M. Capraro menyatakan yang dikutip oleh William N. Bender (2012)

Project Based Learning is an instructional model based on having student confront real world issues and problems that they find meaningful, determine how to addres them, and then act in a collaborative fashion to create problem solution. (artinya: Pembelajaran berbasis proyek adalah model instruksional yang didasarkan pada meminta peserta didik menghadapi masalah dan masalah dunia nyata yang mereka anggap bermakna, menentukan cara mengatasinya, dan kemudian bertidak dengan cara kolabiratif untuk menciptakan solusi masalah.

b. Menurut Nanang Hanafiah dan Cucu Suhana (2009:30).

Model pembelajaran project based learning adalah pendekatan pembelajaran yang memperkenankan peserta didik untuk bekerja mandiri dalam mengkonstruksi pembelajarannya dan mengkulminasikannya dalam produk nyata.

c. Menurut Trianto (2014:42).

Project Based Learning adalah sebuah model atau pendekatan pembelajaran yang inovatif, yang menekankan belajar kontekstual melalui kegiatan-kegiatan yang kompleks.

d. Menurut Made Wena (2009:144).
Model pembelajaran project based leraning adalah model pembelajaran yang memberikan kesempatan kepada guru untuk mengelola pembelajaran di kelas dengan melibatkan kerja proyek. Kerja proyek merupakan suatu bentuk kerja yang memuat tugastugas kompleks berdasarkan kepada pertanyaan dan permasalahan yang sangat menantang dan menuntun peserta didik untuk merancang, memecahkan masalah, membuat keputusan, melakukan kegiatan investigasi, serta memberikan kesempatan peserta didik untuk bekerja secara mandiri.

e. Tim Penyusun Naskah Presentasi Model-model Pembelajaran LPMP (2016).

Salah satu bagian dari pembelajaran aktif adalah project based learning atau model pembelajaran yang berbasis proyek/produk. Model pembelajaran ini menekankan pada hasil akhir dari satu kegiatan pembelajaran, yaitu berbentuk karya, produk, atau portofolio yang dihasilkan oleh peserta didik. Pembelajaran ini dapat dilakukan, baik secara berkelompok maupun individu.

Project based learning menghasilkan produk sederhana yang dapat memvisualisasikan materi yang dipelajari peserta didik dari pemahaman konseptual menjadi pemahaman factual. Pembelajaran ini menggunakan proyek atau kegiatan sebagai media dalam kegiatan pembelajaran. Dalam project based learning, peserta didik melakukan eksplorasi, penilaian, interpretasi, serta sistesis dan informasi untuk menghasilkan berbagai bentuk hasil belajar.

Pembelajaran berbasis proyek/produk berpusat pada peserta didik. Dalam hal ini, guru 
bertindak sebagai fasilitator yang membimbing peserta didik dalam mengeksplorasi, menganalisis, serta melakukan interpretasi terhadap materi yang sedang dipelajari di kelas.

2. Karakteristik Model Pembelajaran Project Based Learning

Karakteristik model pembelajaran Project Based Learning (PjBL) adalah sebagai berikut ( Majid, 2015: 163):

a. Peserta didik membuat keputusan tentang sebuah kerangka kerja;

b. Adanya permasalahan atau tantangan yang diajukan kepada peserta didik;

c. Peserta didik mendesain proses untuk menentukan solusi atas permasalahan atau tantangan yang diajukan;

d. Peserta didik secara kolaboratif bertanggung jawab untuk mengakses dan mengelola informasi untuk mamacahkan masalah;

e. Proses evaluasi dilakukan secara kontinu;

f. Peserta didik secara berkala melakukan refleksi atau aktivitas yang sudah dijalankan;

g. Produk akhir aktivitas belajar peserta didik akan dievaluasi kualitatif;

h. Situasi pembelajaran sangat toleran terhadap kesalahan dan perubahan;

i. Guru sebagai fasilitator, pelatih, penasehat dan perantara untuk mendapatkan hasil yang optimal dengan imajinasi, kreasi dan inovasi dari peserta didik.

3. Kelebihan dan Kekurangan Model Pembelajaran Project Based Learning

a. Kelebihan Model Pembelajaran Project based Learning (PjBL) adalah sebagai berikut ( Majid, 2015:164):

1) Meningkatkan motivasi belajar peserta didik;

2) Meningkatkan kemampuan memecahkan masalah;
3) Membuat peserta didik menjadi lebih aktif dan berhasil memecahkan masalah-masalah yang kompleks;

4) Meningkatkan kolaborasi;

5) Meningkatkan keterampilan peserta didik untuk mengembangkan dan mempraktikkan keterampilan komunikasi;

6) Meningkatkan keterampilan peserta didik dalam mengelola sumber belajar;

7) Memberikan pengalaman kepada peserta didik pembelajaran dan praktik dalam mengorganisasi proyek, dan membuat alokasi waktu dan sumber lain seperti perelengkapan untuk menyelesaikan tugas;

8) Melibatkan peserta didik secara kompleks untuk belajar mengabil informasi dan menunjukan pengetahuan yang dimiliki, kemudian diimplementasikan dengan dunia nyata;

9) Membuat suasana belajar lebih menyenangkan, sehingga peserta didik maupun pendidik menikmati proses pembelajaran.

b. Kekurangan Model Pembelajaran Project Based Learning (PjBL)

1) Memerlukan banyak waktu yang harus diselesaikan untuk menyelesaikan masalah.

2) Memerlukan biaya yang cukup banyak.

3) Banyak peralatan yang harus disediakan.

\section{Pengertian Pendidikan Agama} Islam

Para pakar pendidikan Islam memiliki definisi tentang pendidikan Islam atau pendidikan Agama Islam yang berbeda-beda. Ahmad Tafsir misalnya, ia mendefinisikan pendidikan Islam sebagai "bimbingan yang diberikan oleh seseorang kepada orang lain agar 
ia berkembang secara maksimal sesuai ajaran Islam". (Ahmad Tafsir, 2008:32)

Sedangkan menurut Abuddin Nata (2009:340), pendidikan Islam adalah “ upaya membimbing, mengarahkan, dan membina peserta didik yang dilakukan secara sadar dan terencana agar terbina suatu kepribadian yang utama sesuai dengan nilai-nilai ajaran Islam ". ( Nata, 2009:340)

Berbeda dengan Abuddin Nata, Muhaimin mengungkapkan bahwa Pendidikan Agama Islam merupakan bagian pendidikan Islam. Istilah Pendidikan Islam dapat dipahami dalam beberapa pengertian, yaitu: (1)Pendidikan menurut Islam atau pendidikan Islami, yaitu pendidikan yang dipahami dan dikembangkan dari ajaran dan nilai-nilai fundamental yang terkandung dalam sumber dasarnya, yaitu Al-Qur'am dan alSunnah, (2)pendidikan ke-Islam-an atau pendidikan Islam, yaitu upaya pendidikan ke-Islam-an atau ajaran Islam dan niali-nilainya agar menjadi way of life (pandangan atau sikap hidup) seseorang, dan (3) pendidikan dalam Islam, yaitu proses dan praktik penyelenggaraan pendidikan yang berlangsung dan berkembang dalam sejarah umat Islam. Walaupun istilah pendidikan Islam tersebut dapat dipahami secara berbeda, namun pada hakikatnya merupakan satu kesatuan dan mewujudkan secara operasional dalam satu sistem yang utuh. (Muhaimin, 2008:29-30)

\section{HASIL DAN PEMBAHASAN}

Hasil penelitian implementasi model pembelajaran Project Based Learning $(P j B L)$ dalam meningkatkan hasil belajar peserta didik pada mata pelajaran pendidikan agama Islam di SMP Negeri 7 Kota Tangerang, dapat disimpulkan bahwa implementasi model pembelajaran Project Based Learning $(P j B L)$ dapat meningkatkan hasil belajar peserta didik pada mata pelajaran Pendidikan Agama Islam.

Berdasarkan persentase hasil belajar peserta didik ketika belum menggunakan model pembelajaran Project Based Learning (PjBL) dimana jumlah peserta didik 36 perkelas, dan yang berhasil mencapai ketuntasan belajar minimum sekitar 22 peserta didik yaitu $60 \%$ dari 36 peserta didik, sedangkan setelah menggunakan model pembelajaran Project Based Learning (PjBL) terdapat peningkatan hasil belajar peserta didik sekitar 85\% dari jumlah 36 peserta didik yaitu sekitar 31 peserta didik yang berhasil mencapai ketuntasan belajar minimum pada pembelajaran Pendidikan Agama Islam. Jadi rata-rata pekelas mendapatkan peningkatan sekitar $85 \%$.

Pendidikan Agama Islam yang menekankan kepada aspek moral manusia sebagai makhluk sosial dan ber-Tuhan sehingga membutuhkan penekanan pada proses pembelajarannya. Implementasi model pembelajaran Project Based Learning (PjBL) pada pembelajaran pendidikan agama Islam akan dapat berjalan dengan maksimal jika dijalankan dengan baik sehingga peserta didik dapat memecahkan masalah dan dapat meningkatkan kemampuannya dalam memecahkan masalah.

Pengalaman langsung yang diberikan kepada peserta didik akan memberikan dampak yang baik bagi peserta didik termasuk dalam memecahkan masalah pada mata pelajaran pendidikan agama Islam serta meningkatkan hasil belajar peserta didik.

Implementasi model pembelajaran Project Based Learning (PjBL) dalam proses pembelajaran dapat meningkatkan hasil belajar peserta didik, karena peserta didik diberikan pengetahuan baru, ikut dilibatkan dalam kegiatan pembelajaran, diajarkan bertanggungjawab, berfikir kreatif, dan dapat memecahkan masalah.

Bedasarkan hal tersebut, maka penggunaan model pembelajaran Project Based Learning (PjBL) dapat meningkatkan hasil belajar peserta didik 
pada mata pelajaran pendidikan Agama Islam.

Adapun faktor pendukung dalam implementasi Poject Based Learning $(P j B L)$ adalah: guru mata pelajaran yang professional dalam bidangnya, adanya semangat peserta didik dalam mengikuti pembelajaran bebasis proyek, motivasi peserta didik yang positif dan sarana pendidikan yang memadai.

Adapun faktor penghambatnya adalah: masih ada peserta didik yang malumalu, tidak percaya diri, dan ada yang belum biasa berfikir kritis., hambatan yang datang dari guru dan hambatan pada jam pelajaran yang sangat sedikit dalam satu minggu hanya tiga jam pelajaran (3JP).

\section{KESIMPULAN}

Berdasarkan hasil penelitian dan pembahasan dapat disimpulkan bahwa implementasi model pembelajaran Project Based Learning (PjBL) pada mata pelajaran pendidikan agama Islam dapat meningkatkan hasil belajar peserta didik. Hal ini dapat dilihat bahwa sebelum menggunakan model pembelajaran Project Based Learning (PjBL) hasil belajar peserta didik hanya $60 \%$ yang berhasil mencapai Ketuntasan Belajar Minimum (KBM), akan tetapi setelah menggunakan model pembelajaran Project Based Learning (PjBL) hasil belajar peserta didik meningkat menjadi $85 \%$ yang berhasil mencapai Ketuntasan Belajar Minimum (KBM) .

\section{DAFTAR PUSTAKA}

Al-syaibani, Omar Muhammad Al-Toumy, Filsafat Pendidikan Islam, Jakarta: Bulan Bintang

Bender, N. William. (2012). Project Based Learning:

Differentiating Instruction For The $21^{\text {st }}$ Century, California: Corwin.
Lindawati, Siska Desy Fatmariyanti, Arif maftukhin, "Penerapan Model Pembelajaran Project Based Learning Untuk Meningkatkan Kreativitas Siswa MAN 1 Kebumen", Jurnal Radiasi. Vol.3.No.1

Majid, Abdul. (2013). Strategi Pembelajaran, Bandung: Remaja Rosdakarya.

Masrun dan Martaniah. (1971). Psikologi Pendidikan, Jogyakarta: Yayasan Penerbitan Fakultas Psychologi UGM.

Muhaimin, ec. al. (2004).Paradigma Pendidikan Islam, Bandung: Remaja Rosdakarya.

Mulyasa, E. (2004). Kurikulum Berbasis Kompetensi, Bandung: Remaja Rosdakarya.

Nanang Hanafiah dan Cucu Suhana. (2009). Konsep Strategi Pembelajaran, Bandung: PT. Redika Aditama.

Nata, Abuddin. (2011). Perspektif Strategi Pembelajaran, Jakarta: Kencana.

Suryabrata, Sumadi. (2014). Metodologi Penelitian, Penerbit: PT. Rajagrafindo.

Tafsir, Ahmad. (2004). Ilmu Pendidikan Dalam Perspektif Islam, Bandung: Remaja Rosdakarya.

Tim Penyusun Naskah Presentasi ModelModel Pembelajaran LPMP (2016).

Trianto. (2014). Mendesain Model Pembelajaran Inovatif, Progresif, dan Kontekstual, Jakarta: Prenada Media.

Ula, S. Shoimatul. (2013). Revolusi Belajar, Yogyakarta: Ar-Ruzz Media.

Wena, Made. (2009). Strategi Pembelajaran Inovatif Kontemporer: suatu tinjauan konseptual operasional, Jakarta: Bumi Aksara. 